\title{
Art and sonic mining in the archives: methods for investigating the wartime history of Birmingham School of Art
}

\author{
Absconditi Viscus (or Hidden Entries) is a series of sound compositions based on \\ the history of Birmingham School of Art during the First World War. Sound \\ artist Justin Wiggan explored the concept of historical sonic information that \\ although lost could still potentially permeate within the archival record and the \\ fabric of the school building. Each sound piece has also been synchronized with \\ brainwave frequencies in order to stimulate a listener's brain activity in an \\ attempt to connect them with the time period, the physical building, and the \\ emotional impact of the war. This creative, experimental, and potentially \\ controversial, assertion of phonic excavations and sonic mining as method \\ challenges us to rethink both affect and the archival record in relation to the \\ history of education.
}

Keywords: art; archives; sound; First World War

\section{Introduction}

Absconditi Viscus by sound artist Justin Wiggan is a series of sound compositions based on the history of Birmingham School of Art during the First World War. As an artist's creative engagement with an historical archive, it can be situated as part of a growing practice in contemporary art. As an art project centred on the concept of sonic mining, it has prompted me to rethink the nature of the archival record in relation to the history of art education and the relationships between affect, archive, historiography and history. Unapologetically, it is this methodological aspect of the project that this paper discusses rather than the history of the impact of the First World War on the School. Archives and archival research are arguably the mainstay of history, and for the history of education it is often to the school log books, text books, newspapers reports, and committee papers that historians turn as the textual, written documentary records of past educational practices and histories. Visual sources in the archives may also be consulted, for example through photographs of pupils, teachers and classes in action. For the history of 
art education the archival sources available to the historian have also included children's and students' drawings and sketches, even artefacts created in, or for, classes. However, in addition to the growing emphasis on non-textual sources ${ }^{1}$ and in the context of the emergence of a field of sensory history ${ }^{2}$, what might it mean for our understanding of education to consider its sonic history? Can historians mine the archives for the sound of educational experiences past in the same way as an artist?

\section{Artists \& archives - creative practice as method}

Before focussing on Justin Wiggan's project, it is worthwhile to first consider the context of artists working with archives in contemporary art practice. Over a decade ago, prominent art critic and historian Hal Foster drew attention to the presence of a distinct archival impulse in contemporary art as artists sought to make historical information, often lost or displaced, physically present by reorganising bodies of alternative knowledge or counter memory. ${ }^{3}$

One example was on display in Worcester City Art Gallery and Museum in close proximity to and at the same time as the 2016 History of Education Society conference held in Malvern. The work in question was Jeremy Deller's The Battle of Orgreave (An Injury to One is an Injury to All), (2001). Deller orchestrated the reenactment of a relatively recent historical event from the Miners Strike in the UK of 1984-1985. One of the most violent clashes between strikers and the authorities took

\footnotetext{
${ }^{1}$ For example see: Karen Harvey, ed., History and Material Culture: a student's guide to
} approaching alternative sources, (Abingdon: Routledge, 2009); Ludmilla Jordanova, The Look of the Past: Visual And Material Evidence In Historical Practice, (Cambridge: Cambridge University Press, 2012)

2 Mark M. Smith, 'Looking Back: The explosion of sensory history', The Psychologist, 23:10 $860-863$

${ }^{3}$ Hal Foster, 'An Archival Impulse', October, 110 (Fall 2004), 3-22 
place on 18 June 1984 near the Orgreave coking plant. Jeremy Deller's artwork was a spectacular recreation of that day, whose participants included former miners and former policemen, as well as members from Civil War reenactment societies. The reenactment was the subject of a documentary film directed by Mike Figgis, which is now exhibited alongside objects, images and audio recordings from the artist's own archive of research materials created for the reenactment of the battle and original primary source material that he collected. The exhibition is both contemporary artwork and educational display; it merges historical and archival documents with documentation of a reenactment, facts with their fictive recreation.

In his 2004 article, Foster argued that the way a number of artists have used historical material in recent years reflected a desire 'to connect what cannot be connected'. Contemporary artists' explorations of new ways of looking at the archive have highlighted the significance given to the archive, whether official, collective or personal, as the means by which historical knowledge and memory are collected, stored and recovered. ${ }^{4}$ In this way we can understand Deller's The Battle of Orgreave as a conscious attempt to bring into the archive, and thus into the historical record, the violence of an event in a recent political struggle and also at the same time to document the individual, personal stories of both sides, the miners and policemen who had experienced it. It is of course inflected with Deller's own political positionality, as the sub-title reveals 'An injury to one is an injury to all' and the narrative depicted through the documentary film and the timeline in the exhibition, clearly articulate his view that the violence of the battle at Orgreave is symptomatic of a wider attack on trade unions in the period as a result of which he believes we are all worse off.

\footnotetext{
${ }^{4}$ Charles Merewether, ed., The Archive, Documents of Contemporary Art, (London: Whitechapel and The MIT Press, 2006)
} 
In Deller's recreation of the Battle of Orgreave we can discern a conscious attempt to document and recreate an authentic representation of the events of the day, even if that authenticity is not singular or authoritative but instead constructed from multiple viewpoints. However, in engaging with archives contemporary artists have often demonstrated both a creative ambivalence towards, and an informed critique of, notions of authenticity and authority - key concepts in historical enquiry. In particular Foster examined the work of three artists whose work for him embodied this archival impulse. ${ }^{5}$ Thomas Hirschhorn is a Swiss artist whose sculptural installations have encompassed altars, shrines, kiosks and monuments to cultural figures including writer, artists and philosophers. These installations are often crudely constructed and can contain an array of images, texts and objects. For example, Foster illustrates his Deleuze Monument (2000) in Avignon France encompassed of a rock inscribed with a quotation, an altar, a monumental sculpture and a library of books by and about the philosopher Gilles Deleuze. Tacita Dean, whose artworks take the form of photographs, blackboard drawings, sound pieces and films, is an artist whose works are often based on lost figures and forgotten stories. Foster describes as an example her triumvirate of film works inspired by Donald Crowhurst's failed attempt to be the first sailor to complete a nonstop solo voyage around the world in 1968. Disappearance at Sea I (1996) shows an alternating sequence of the bright lights and blank horizons at lighthouses and Disappearance at Sea II, (1997) reveals a panorama of the sea filmed from the perspective of a rotating lamp in a lighthouse. In the third film, Teignmouth Electron (2000), Dean documents the remains of what is purported to be the wreckage of Crowhurst's boat. Foster's third artist is Sam Durant, an American artist whose work eclectically reinterprets and represents elements of mid-twentieth century American

\footnotetext{
${ }^{5}$ Foster, An Archival Impulse, 2004
} 
history. For example, Foster illustrates Chair \#4 (1995) in which Durant depicts an iconic Eames shell chair, a classic of mid-century design, upturned on the floor. Although these art works might not appear at first glance to represent or reproduce archives, for Foster 'the work in question is archival since it not only draws on informal archives but produces them as well, and does so in a way that underscores the nature of all archival materials as found yet constructed, factual yet fictive, public yet private., ${ }^{6}$

As Foster himself admitted, contemporary artists are of course not the first to engage with archives and the archival as the conceptual basis of their work. In The Big Archive (2008) Sven Spieker traces the engagement of artists with archives and the archival from the late nineteenth century through to the early twenty first century, referencing Alexander Rodchenko, Marcel Duchamp, Max Ernst, Andy Warhol, Gerhard Richter, Susan Hillier and others. ${ }^{7}$ The engagement of artists with archives thus has an impressive pedigree and context in which Justin Wiggan's project on the wartime history of the Birmingham School of Art can be situated. As artists have worked with archives and the archival, their creative methodologies and approaches have utilised, as well as arguably expanded and contested, the methods of historical research. Wiggan's project explicitly posits a new methodology of sonic excavation as both creative act and historical research method.

\section{Justin Wiggan and the Absconditi Viscus Project}

Birmingham School of Art and its grade one listed building in Margaret Street has a significant place in the history of art and design education in the UK. This significance comes as the first municipal art school in terms of funding and control, and as the first

\footnotetext{
${ }^{6}$ Foster, An Archival Impulse, 4

${ }^{7}$ Sven Spieker, The Big Archive: art from bureaucracy, (Cambridge MA: The MIT Press, 2008)
} 
purpose-built art school building in the country. It is the association of the Birmingham School with the Arts and Crafts movement and the introduction of executed design as pedagogy in the late nineteenth century that has received the greatest attention from historians. ${ }^{8}$ Justin Wiggan, then artist in residence with the School of Art, proposed instead to explore the history of the School during the First World War (1914-1918) and he was actively encouraged as it was a relatively unexamined period in the School's history. It was also a timely suggestion in that it did of course also relate to a national focus on the centenary of the First World War, and Wiggan was able to secure additional support for his project from the Arts and Humanities Research Council's (AHRC) World War One Engagement Centre: Voices of War and Peace. ${ }^{9}$ The artist titled his project Absconditi Viscus and it resulted in a series of five sound compositions based on the changes to the Birmingham School of Art during First World War. Each sound composition relates to a year of the war. Leading to the sound compositions, QR $\operatorname{codes}^{10}$ were engraved on Indian Red Stone tiles and then inlayed with gold leaf by local tile mason Paul Houldey. One of these tiles has been placed on each floor of the School of Art building in Margaret Street in ascending order relating to every year of the War, from 1914 in the basement to 1918 on the top floor. The artist intended that

${ }^{8}$ Alan Crawford, By Hammer and Hand: Arts and Crafts Movement in Birmingham, (Birmingham: Birmingham City Council 1984); John Swift, 'Birmingham and its Art School: Changing Views 1872-1875', Journal of Art and Design Education, 7 no.1, (1988), 5-29; John Swift, Changing Fortunes: Birmingham School of Art Building 18801995 (Birmingham: Article Press, 1996); Sian Vaughan, 'The Art School, Society of Artists and the City' in A Place for Art: the story of the Royal Birmingham Society of Artists, ed. Brendan Flynn, (Birmingham: RBSA 2014), 40-44.

${ }^{9} \mathrm{http} / / / \mathrm{www}$. voicesofwarandpeace.org

${ }^{10}$ A QR code (abbreviated from Quick Response Code) is a type of matrix barcode. It is a machine-readable optical label that normally contains information that links to a website. 
people are able to access the sound files using their smart phones to read the QR code on the tile which leads them to the website and the hidden content of each sound piece. ${ }^{11}$ Absconditi Viscus is roughly translated from the Latin by the artist as 'hidden entries'. The artist has created 'hidden entries' to the history of the building and the war-time history of art education through the physical folding and injection of sound pieces into the architecture of the building. The history is visible yet hidden at the same time, as the tiles are visible yet the sound works they lead to must be actively sought out.

These tiles and sound art pieces were the culmination of an 18 month participatory arts project that ran from October 2014 to March 2016. Wiggan's methodology was a combination of the more traditional research methods of history, participatory art practices, and more innovative methods of sonic excavation. Wiggan himself undertook archival research in the minute books of the Birmingham School of Art in the Art and Design Archives held at Birmingham City University, thoroughly reading all the records held pertaining to the period of the War. He also ran a series of participatory workshops with current students and members of the public, bringing them in to the archives to look at the minute books, photographs and artworks from the period. With these participants, he chose episodes and events documented in the archives to explore further and to inform the composition of the sound art pieces. As a research diary and project communication tool Wiggan set up a Facebook community that documents the progress and process of the project and includes excerpts from the

\footnotetext{
${ }^{11}$ The sound pieces are also available directly from the website: http://marg.cocsi.org
} 
minute books and archival records, as well as video and audio clips of the sonic investigations. $^{12}$

As well as being an artist, Justin Wiggan also describes himself as a 'Sonic Detective'. Through his Centre of Curious Sonic Investigation, he set out to explore the sonic history of the art school building and its records. In the immersive workshops, his participants also became Sonic Detectives and were encouraged to seek out references to sound and think about how art educational practice might have sounded during the period of the war. This emphasis on sound is evident in the archival research undertaken. For example, in his artist's notes on Research Strands from Jan 1916 to July 1916, Wiggan pick's out two strands that drew his attention:

1. Office clerk W.G Hughes went from land locked Birmingham office at Margaret Street to be stationed as a Coast Watcher. Linking identity and habit to overlay his recognizable terrain over the new location of placement. Sea of paperwork over the ocean / paper cliffs and the relative phonic structures of the ocean compared to the paper activity noise.

2. New Lighting Regulations - cosmetic changes to environment, black out screens and effect on dampening sounds, tones generated from bulbs. ${ }^{13}$

With his participant Sonic Detectives he then recorded the sounds of piles of paper fluttering down the staircases in the School of Art building, experimenting with the sounds produced to see if they could be compared to the sounds of ocean waves. Whilst the artist's allusions to a sea of paperwork and paper cliffs might be anachronistic, it is a poetic way of drawing attention to the changing environments the office clerk would have encountered. We can see that he is not only identifying changes in the staff and

\footnotetext{
${ }^{12}$ Absconditi Viscus Facebook community, https://www.facebook.com/pg/Absconditi-Viscus349244631892604/

${ }^{13}$ Absconditi Viscus Facebook community, post by the artist on 3 October 2015
} 
environment of the art school building, he is reflecting on the sonic implications of those changes to consider how did the various environments sound different as a result of war-time activities.

Some of the workshops took place in the Art and Design Archives, others in the Margaret Street School of Art building. The workshops used sound-recording software and apps including PitchLab Guitar Tuner and Recho, an app which lets you record sounds and tie them to the place they were recorded (i.e. you can only hear them if you are stood exactly where they were recorded). The artist and his Sonic Detective participants took sonic frequency readings from documents in the Archives and from the rooms and spaces within the School of Art building itself. Wiggan and the participants also sought out 'found sounds' and created, arguably recreated, sounds relevant to the events recorded in the minute books that they were investigating. The final sound pieces include, for example, sounds such as gunshots in reference to reports of injured staff returning to teach at the school. The sounds of window cleaning are included as it appeared from the committee minutes to have been a constant source of frustration during the period. Wiggan was also keen to include the sounds of repairing watches in reference to his discovery of the concerted efforts made by the Birmingham School of Art and its constituent School of Jewellery to retrain returning disabled soldiers for the local watch and jewellery trades as these were skilled trades that were based at a bench and were thus seen to be able to accommodate the injured soldiers limited mobility.

The five sound art pieces created, each lasting between 20 and 30 minutes, are not narratives or recreations of soundscapes. They are different to the use of oral histories and soundscapes in museum interpretation and display for example. Each piece is an artistic and creative composition that is not necessarily easy to interpret. There are 
clues on the website where the sound pieces are held. Each sound piece is based on a year of the war, from 1914 to 1918 , and for each year Wiggan has listed the influences and elements of the piece titled as 'Sonic Clues'. Those for 1918 include:

- Training afternoon classes for disabled soldiers successful

- Ida Baker student, attended twice then put in sanatorium until February

- Two additional woman cleaners employed due to extra work from room take over from FCC

- Increase in class attendance and return was due to an awaking on the part of the people to the importance of education, and to the more earnest spirit which has resulted from the strenuous exertions in connection with the war. ${ }^{14}$

Whilst these are almost akin to a track list or credits, the clues are quite oblique. It is difficult to decipher which elements of the composition relate to Ida Baker's sanatorium stays, or to speculate as to why she was confined to the sanatorium whilst listening to the compositions. It takes pre-existing knowledge to know that FCC refers to the Food Control Committee that was lodged within the School of Art Building. Some of the sonic clues paraphrase or mimic the language of the Minute Books of the School of Art, albeit unreferenced and with a degree of artistic license. ${ }^{15}$

Wiggan's interest in the First World War period was to find out what effects the War had on being a student and the curriculum and activities at the School of Art. He wanted to explore how the trauma of the War became embedded into the life of the

\footnotetext{
${ }^{14}$ http://marg.cocsi.org/c1918/

${ }^{15}$ For example the clue statement about the increase in class attendance is actually a paraphrasing of minute 2428 at the School of Art Sub-Committee meeting on 9 October 2017 and thus not actually a comment on attendance at the School in 1918. School of Art Sub-Committee Minutes, vol. 12, 1916-1921, 136, archival ref SA/AD/2/12.
} 
building and in the lives of those who worked within it. So he synchronised each sound piece with different brainwave frequencies in an attempt to stimulate the emotional impact of the war for the listener. ${ }^{16}$ Whilst the correspondence of brainwaves as differing oscillation frequencies of neurons in the brain to states of conscious is generally accepted in neuroscience, ${ }^{17}$ Wiggan outlines a more poetically nuanced set of associations. He explains that tile one on 1914 is pitched for Delta Waves $(0.5$ to $3 \mathrm{~Hz})$, associated with deepest meditation and sleep. Tile two on 1915 is pitched for Theta Waves ( 3 to $8 \mathrm{~Hz}$ ) which he describes as 'our gateway to learning and memory. In theta we are in a dream...it's where we hold our 'stuff', our fears, troubled history, and nightmares.' Is the artist here alluding to the reality of a war that was not over by Christmas perhaps? Tile three for 1916 is pitched for alpha waves ( 8 to $12 \mathrm{~Hz}$ ) described as 'the power of now' and learning. Tile four for 1917 is pitched to beta waves $(12$ to $38 \mathrm{~Hz})$ described as a state in which attention is directed to tasks and problem solving. Through to tile five for 1918, pitched for Gamma waves (38 TO 42 $\mathrm{Hz}$ ), active when in states of universal love, altruism, and the 'higher virtues', linked here by the artist to the coming of peace. ${ }^{18}$

Listening to the sound pieces, we recognize perhaps some of the constituent sounds, wonder what other sounds signify but the overall composition creates an atmosphere, an environment, a tone (in all senses) and mood. As the artist says: 'The thing about sound is because you can't see it it's quite romantic, and it can do some

\footnotetext{
${ }^{16}$ Justin Wiggan correspondence with the author, November 2016

${ }^{17}$ For example see: Gyorgy Buzsaki, Rhythm of the Brain, (Oxford: Oxford University Press, 2006)

${ }^{18}$ Justin Wiggan correspondence with the author, November 2016
} 
strange emotional things to you'. ${ }^{19}$ Whether or not the sound pieces do provoke resonances with the emotions and states of consciousness intended by the artist is debatable, from personal experience I can state that in creating at atmosphere that they do provoke a response, one that is cognitive, emotional and embodied, albeit one that is hard to describe.

\section{Sonic mining and sonic residue as method}

Justin Wiggan's project explored the concept of historical sonic information that although lost could still potentially permeate within the archival record and the fabric of the school building. This creative, experimental, and potentially controversial, assertion of phonic excavations and sonic mining as method challenges us to rethink both affect and the archival record in relation to the history of education.

Wiggan explains that his interest in sonic mining and the inspiration behind the project came when he heard that the classical Greek writer, Antiphanes, had written about words freezing in winter. ${ }^{20}$ The Greek first century essayist Plutarch does comment that Antiphanes remarked on a city that was so cold that words spoken in winter froze as soon as they were uttered and that it was only later as the words thawed in summer that people heard them. ${ }^{21}$ Rather than as a plausible anecdote about the classical Greek writer, it is now thought more probable to have been the $4^{\text {th }}$ century BC Antiphanes of Berge than the Greek comic dramatist that Plutarch is referring to, and as

\footnotetext{
${ }^{19}$ Justin Wiggan, artist's talk at the Absconditi Viscus launch event, 17 March 2016 at Birmingham School of Art

${ }^{20}$ Justin Wiggan correspondence with the author, November 2016

${ }^{21}$ William Hansen, Ariadne's Thread: A Guide to International Tales Found in Classical Literature, (New York: Cornell University Press, 2001)
} 
an example of exaggeration and falsehood..$^{22}$ Nonetheless is it an idea that has inspired and persisted in literature, for example a similar tale appears amongst the tall tales of absurd heroic feats of Baron Munchausen, originally published in 1785. In this instance the notes of a musical instrument are frozen within it, and the horn only sounds once it is hung near a fire and thaws. ${ }^{23}$ For the artist Justin Wiggan, the story of Antiphanes suggested that sounds from the past could be preserved and found at a later date.

Wiggan cites another source of inspiration that he came across whilst researching Antiphanes - the field of archaeoacoustics, ${ }^{24}$ which is the use of acoustical study as a methodological approach within archaeology. Wiggan has drawn particularly on an early interpretation of the idea of archaeoacoustics which is more akin to the tall tales of Antiphanes and Baron Munchausen in the belief solid matter can soak up sound and keep it trapped until it escapes slowly or is released at a date in future. In the late 1960s archaeologists explored the idea that therefore acoustic phenomena could have become encoded in ancient artifacts. For instance, the idea that a pot or vase could be 'read' like a gramophone record for messages from the past, sounds having been encoded into the turning clay as the pot was thrown. Or so archaeologist Richard G. Woodbridge claimed to have discovered in $1969 .^{25}$ This early work was followed up in 1993 when Paul Astrom, an archaeology professor and Mendel Kleiner, a professor of acoustics, performed experiments and reported that they could recover some sounds. ${ }^{26}$

\footnotetext{
${ }^{22}$ Hansen, Aridane's Thread, 147

${ }^{23}$ Rudolf Erich Raspe, 1786, Baron Munchausen's Narrative of his Marvellous Travels and Campaigns in Russia, (London: the author, 1786) 48

${ }^{24}$ Justin Wiggan correspondence with the author, November 2016

${ }^{25}$ Richard G. Woodbridge, 'Acoustic Recordings from Antiquity', Proceedings of the IEEE, 57 no.8 (1969): 1465-1466

${ }^{26}$ Mendel Kleiner and Åström, Paul (1993), 'The Brittle Sound of Ceramics - Can Vases Speak? Archeology and Natural Science, 1 (1993), : 66-72
} 
This more controversial application of archaeoacoustics has been generally discredited in archaeology. Nonetheless, archaeoacoustics has become a recognized field of experimental archaeology, now focusing on the acoustic properties of archaeological sites in relation to understanding the spatial practices of previous humans rather than as recordings of lost sounds. ${ }^{27}$ Admittedly this has tended to focus on Neolithic sites and their possible ritual uses ${ }^{28}$ rather than on early twentieth century education. Justin Wiggan's project and its focus on sonic investigation points to the potential of considering methodologies from other disciplines such as archaeology in examining the history of art education.

The archival impulse in contemporary art has often been closely associated with archaeological metaphors and processes. So again here we can locate Absconditi Viscus as part of a contemporary art practice. As the archival continues to be engaged with by contemporary artists, their art has encompassed practices of archive construction, archaeological investigation, record keeping, the use and re-use of archived materials. ${ }^{29}$ As Enwezor states in his catalogue essay for Archive Fever, the 2008 exhibition at the International Centre of Photography in New York:

${ }^{27}$ For example see: Dana C. E. Millson, ed., Experimentation and Interpretation: the Use of Experimental Archaeology in the Study of the Past, (Oxford: Oxbrow Books 2010); Chris Scarre, and Graeme Lawson, (eds) Archaeoacoustics, (Cambridge: McDonald Institute Monographs 2006); Rupert Till, 'Sound Archaeology: An Interdisciplinary Perspective', in Archaeoacoustics: The Archaeology of Sound, ed. Linda Einix, (Malta: OTS Foundation, 2014).

${ }^{28}$ Aaron Watson and David Keating, 'Architecture and sound: an acoustic analysis of megalithic monuments in prehistoric Britain', Antiquity 73 (1999), 325-36; Paul Devereux and Tony Richardson, Stone Age Soundtracks: The Acoustic Archaeology of Ancient Sites, (London: Vega, 2001)

${ }^{29}$ Ernst van Alphen, Staging the Archive: art and photography in the Age of New Media, (London: Reaktion Books, 2014) 
Artists interrogate the self-evidentiary claims of the archive by reading it against the grain. This interrogation may take aim at the structural and functional principles underlying the use of the archival document, or it may result in the creation of another archival structure as a means of establishing an archaeological relationship to history, evidence, information, and data that will give rise to its own interpretive categories. ${ }^{30}$

The concept of sonic mining, and the excavation of sonic residue as proposed by Justin Wiggan suggests another possible archival structure and source of information for historians of art education in the fabric of the building of the School of Art itself. Wiggan took recordings of the room frequencies and incorporated these into the compositions for the sound pieces. He suggests that these frequencies are in part formed by the trauma and changes to the activities taking place within the School during the war. ${ }^{31}$ Whilst Wiggan took sound readings from the School of Art building itself, and even from the pages of the minute books, it is difficult to ascertain whether or not he actually believed he was excavating sounds trapped since the period of the First World War. To be honest, I have been unable to get a straight answer from him, and maybe truth and fact is not the issue here.

At the same time as viewing the archival impulse in art as archaeological, artists have often demonstrated both a creative ambivalence towards, and an informed critique of, notions of authenticity and authority. To give just one example that happens to relate to art education, Jamie Shovlin's art installations have illustrated the creative potential and persuasive power of the display of fictive archives in works such as Naomi V. Jelish (2004). This artwork is an archive of drawings and documents by a missing teenager supposedly kept by her teacher and exhibited alongside newspaper cuttings and diaries.

\footnotetext{
${ }^{30}$ Okwui Enwezor, Archive Fever: uses of the document in contemporary art, (New York: International Centre of Photography, New York and Steidl, 2008): 18

${ }^{31}$ Justin Wiggan correspondence with the author, November 2016
} 
Although exhibited as an archive, with the accompanying documentation and interpretation testifying to the history of the schoolgirl artist, in reality the entirety of the archive and its display was created by the artist Jamie Shovlin. This is underscored by the fact that the names of both the school girl and her teacher, Naomi V. Jelish, and John Ivesmail, are anagrams of the artist's own name. In a more political act, artist Walid Raad created a fictive archive as a pointed critique of the civil war in the Lebanon during the 1970s to the 1990s in which 'borrowing the conventions of the historical novel, the Atlas Group Archive deploys fictional characters - historians, interpreters, witnesses, and archivists - whose investigations and commentary illuminate the disputed terrain of the war's recollections' ${ }^{32}$ Fiction and fictive archives are here used to draw attention to a history viewed as neglected.

For such artists working creatively with archives and the archival, truth and authenticity are contested and challenged alongside a questioning of the control and power implicit in defining the authentic, the evidentially valid. Issues of power and control are central to many contemporary discourses of archivalisation in art theory and practice, in which the archival can be understood as a Foucauldian 'system of discursivity' that establishes the possibility of what can be said. ${ }^{33}$ Referencing Derrida's influential deconstructive analysis of authority and the archive in Archive Fever,

\footnotetext{
${ }^{32}$ Enwezor, Archive Fever, 36

${ }^{33}$ Michel Foucault, The Archaeology of Knowledge and the Discourse on Language, trans Alan. M. Sheridan Smith, (New York: Pantheon books 1972): 128-130; Marlene Manoff, 'Theories of the Archive from Across the Disciplines', portal: Libraries and the Academy, 4 no.1 (2004), 9-25
} 
Enwezor points out that 'artists enact the archival fantasy as well as the archontic function of the historian, translator, curator, pedagogue'. ${ }^{34}$

Admittedly parallel developments are also focusing attention on these questions outside contemporary art including an archival turn in other disciplines recognised within the professional archival field itself. This recognition is partly in response to the development of both community archives and archival activism, even what has been termed archival banditry. ${ }^{35}$ Perhaps artists are not strictly unique in their approach, however the expectation that artists will bring divergent thinking and new approaches to archives means that they are well-placed to make what Stuart Hall terms 'an engagement, an interruption in a settled field'. ${ }^{36}$ The question for the history of education, and history more broadly, is what interruption might artists' productively make in a field in which, whilst a 'cult of the archive' persists ${ }^{37}$ and archival research is still seen as 'paradigmatic [as] a disciplinary marker', ${ }^{38}$ it has already been recognized that 'the archive itself - traditionally regarded as authoritative - is increasingly

${ }^{34}$ Enwezor, Archive Fever, 40; Jacques Derrida, Archive Fever: a Freudian impression, trans Eric Prenowitz, (Chicago: The University of Chicago Press, 1995)

${ }^{35}$ Alexandrina Buchanan, 'Strangely unfamiliar: ideas of the archive from outside the discipline' in The Future of Archives and Recordkeeping, ed. Jennie Hill, (London: Facet Publishing, 2011), 37-62; Jeanette A. Bastian and Ben Alexander, Community archives the shaping of memory, (London: Facet Publishing, 2009); Valdan Vukliš and Anne J. Gilliland, 'Archival Activism: emerging forms, local applications' in Archives in the Service of People - People in the Service of Archives, ed. Bojana Filej, (Maribor, Slovania: Alma Mater Europea 2016), 14-25; Verne Harris, 'Hauntology, Archivy and Banditry: an Engagement With Derrida and Zapiro', Critical Arts, 29: sup1 (2015), 13-27 ${ }^{36}$ Stuart Hall, 'Constituting an archive', Third Text, 15:54 (2001), 89-92, 92, italics in original ${ }^{37}$ Ludmilla Jordanova, History in Practice, (London: Hodder Education 2006), 161-163

${ }^{38}$ Michelle T. King, 'Working with/in the archives' in Simon Gunn and Lucy Faire, eds., Research Methods for History, second edition, (Edinburgh: Edinburgh University Press, 2016, 15-30): 15 
scrutinized for ideological distortion' ${ }^{39}$ Indeed, Enwezor's argument that artists interrogate the archive by reading it against the grain can be seen as an echo of historian Raphael Samuel's assertion nearly 30 years earlier that in seeking evidence in archives, historians 'are having to extract meaning against the grain of the documentation however much it may appear to be obedient to our will'. ${ }^{40}$ As John Tosh has recently stated in his practical guide to methods and approaches for history students, 'when properly applied, the critical method enables the historian to make allowances for both deliberate distortion and the unthinking reflexes of the writer' when interpreting documents in the archive. ${ }^{41}$ In Absconditi Viscus, the interruption that Justin Wiggan makes is twofold. Firstly his assertion of sonic mining as method is a direct challenge to more traditional notions of authenticity, evidence and types of historical record. Secondly his sound art pieces intentionally set out to physically unsettle those who listen to them, which can be seen as an interruption in relation to affect and in both the archival and historical fields

Justin Wiggan's sound pieces are first and foremost art works, they are his own creative sound compositions based on selection and recreation of sounds he has associated with the war-time history of the Birmingham School of Art through the historical research undertaken by himself and his workshop participants. Leaving aside for the moment the question of the plausibility of the excavation of sonic residue, the sound compositions of Absconditi Viscus are undoubtedly works of the imagination. As an artist, Wiggan did not aim primarily to write history through sound but to create art,

\footnotetext{
${ }^{39}$ John Tosh, The Pursuit of History: aims, methods and new directions in the study of history, (London: Routledge, 2015): 98

${ }^{40}$ Enwezor, Archive Fever, 18; Raphael Samuel, ed., People's History and Socialist Theory, (London: Routledge \& Kegan Paul, 1981), xlv

${ }^{41}$ Tosh, The Pursuit of History, 153
} 
thus foregrounding the interpretative and creative artistic process. There is perhaps not so much a disjuncture here as might first be supposed between the methods of the artist and the historian, although there is arguably a difference in how their works are perceived by others. Whilst in the popular imagination the view persists that there is a singular, factually correct history, historians increasingly recognise the role of imagination in the writing of history. As Antoinette Burton outlines in a book discussing the interrelationship of facts and fiction in the writing of history, 'history is not merely a project of fact-retrieval... but also a set of complex processes of selection, interpretation, and even creative invention ... many historians operate under the assumption that history is a highly interpretative act ${ }^{42}$ In their expanded discussion of the complex and contested relationships between the methods and disciplines of history and the archival profession, Blouin and Rosenberg state that: 'Processing the past through a skilfully told story, in other words, can transcend the objective principles of archival verification ... The most rigourous archival scholarship always leaves room for imagination in the historians craft. ${ }^{43}$ Even John Tosh admits that 'any attempt to reconstruct the past presupposes an exercise of imagination, because the past is never completely captured in the documents which it left behind. ${ }^{44}$ That Absconditi Viscus is based on a creative interpretation of the historical records and the reconstruction of the sounds imagined to have been heard in the past is therefore perhaps not so distant to the traditional methods of historians.

\footnotetext{
${ }^{42}$ Antoinette Burton, Archive Stories: facts, fictions and the writing of history, (London: Duke University Press, 2005): 7-8

${ }^{43}$ Francix X. Blouin Jr. and William G. Rosenberg, Processing the Past: contesting authority in history and the archives, (Oxford: Oxford University Press, 2011): 74

${ }^{44}$ Tosh, The Pursuit of History, 142
} 
Wiggan's assertion of actual sonic residue and sonic excavation as historical method is more problematic and controversial. Such arguments have been discredited within the field of archaeoaccoustics and there is little if any reliable evidence to support his assertions in relation to the history of art education. However, the description of the artist and his workshop participants as Sonic Detectives has a poetic resonance that is intriguing. I would argue that rather than accepting it as a literal process of mining for sonic residue as captured sounds, the artist's assertion of sonic excavation as a method is constructive if considered as a heuristic device, a trope through which to reconsider the archival record for the Birmingham School of Art during the period of the First World War. Wiggan and his Sonic Detectives draw our attention to sounds in relation to education. In his recent book examining sounds across history, Trevor Cox, a Professor of Acoustic Engineering, records how he has been working in recent years 'researching how poor acoustics and high noise levels in classrooms affect learning, ${ }^{45}$ Surely if it is recognised as a factor in contemporary education, considering the role of sound in the history of education is a fertile territory for historical enquiry. The concept of a sonic detective encourages us to wonder how and where the sounds of the past can be sought out, and with what results.

Indeed, Wiggan's art project and concept of sonic detectives can be situated in relation to the growing field of sensory history that includes work on the history of education. Since the late twentieth century, historians have examined the potential of approaching history through the lens of different senses beyond the visual with its focus

\footnotetext{
${ }^{45}$ Trevor Cox, Sonic Wonderland: a scientific odyssey of sound, (London: The Bodley Head, 2014), 15
} 
on the written word and captured visual image. ${ }^{46}$ Mark M. Smith provides an authoritative and useful survey of the field and its emergence. ${ }^{47}$ The establishment of the book series Studies in Sensory History in 2011 by the University of Illinois Press has given further recognition and impetus to this growing field. The emergence of sensory history has also begun to touch the history of education. A notable and early example is a Gary McCulloch's highlighting of the broad sensory register that both informed and is evidenced in the work of Assistant Schools Commissioner James Bryce in Victorian Britain, with the dual aim 'to help develop the potential value of sensory history in the history of education as well as to highlight substantial insights into the nature of middle-class education in England in the 1860s'. ${ }^{48}$ Whilst McCulloch focuses particularly on Bryce's olfactory responses to the places of education he visits, he also draws attention to the sounds of Victorian education. Sound has been a prominent focus within sensory history, for example in his book on the history of noise David Hendry identifies how the study of sound fits within this new frontier of sensory history. ${ }^{49}$ The period of the First World War has attracted attention as part of this new frontier, which is of particular relevance to my examination of Absconditi Viscus. Mike

\footnotetext{
${ }^{46}$ For examples see: Alain Corbin, The Foul and the Fragrant: Odor and the French Social Imagination (Leamington Spa: Berg, 1986); John M. Picker, 'The soundproof study: Victorian professionals, work space, and urban noise', Victorian Studies, 42:3, (1999) 427-453; Laura Gowing, L. (2003). Common Bodies: Women, Touch and Power in Seventeenth-Century England (New Haven: Yale University Press, 2003); Michael Prestwich C. M. Woolgar, The senses in late medieval England (New Haven, CT: Yale University Press, 2007).

${ }^{47}$ Mark M. Smith, Sensory history, (Oxford: Berg, 2007)

${ }^{48}$ Gary McCulloch 'Sensing the realities of English middle-class education: James Bryce and the Schools Inquiry Commission, 1865-1868, History of Education, 40:5 (2011), 599-613, 600

${ }^{49}$ David Hendry, Noise: a human history of sound \& listening, (London: Profile, 2014): x
} 
Goldsmith, a scientist, focuses a chapter in his book on sound on the technological developments in relation to acoustics during the First World War including early forms of radar in coastal sound mirrors, underwater hydrophones (underwater microphones) and forays into ultrasonic echo-location. ${ }^{50}$ In contrast Hendry devotes a chapter to considering the experience of the sounds of battle on soldiers in the trenches in the First World War and the long-term consequences for the men of living with the memories of the noise. ${ }^{51}$ Hendry states that he is interested in the social history of sound: 'this means a special fascination in what follows with the subjective aspects of sound: what it actually felt like to experience certain sounds in certain places at certain times in history'. ${ }^{52}$ In this he references R Murray Schafer, described as the 'grandfather of acoustic ecology' having first popularised the term 'soundscape' in the $1970 \mathrm{~s},{ }^{53}$ who asked 'what is the relationship between humanity and the sounds of its environment and what happens when those sounds change? ${ }^{, 54}$ In many ways this is the same question that Wiggan's art project encourages us to consider - how did the soundscape of the

${ }^{50}$ Mike Goldsmith, Discord: The story of noise, (Oxford: Oxford University Press, 2012): 151157

${ }^{51}$ Hendry, Noise, 269-281

${ }^{52}$ Hendry, Noise, x- xi. He positions his own work as different to more intellectual considerations of sound in history. He references as exemplars: Hillel Schwarz, Making Noise: from Babal to the Big Bang and Beyond, (New York: Zone, 2011); Veit Erlmann, Reason and Resonance: A history of modern aurality, (New York: Zone, 2010). In contrast Hendry aligns himself with a more subjective approach pioneered by: Mark M Smith, ed., Hearing History: A Reader, (London: University of Georgia Press, 2004); Richard Cullen Rath, How Early America Sounded, (New York: Cornell University Press, 2003); Emily Thompson, The Soundscape of Modernity: Architectural acoustics and the culture of listening in America 1900-1933, (Cambridge MA: MIT Press, 2002).

${ }^{53}$ Cox, Sonic Wonderland, 17

${ }^{54}$ Raymond Murray Schafer, 'The Soundscape', in Sound, Documents of Contemporary Art Series, ed. Kelly Caleb, (London: Whitechapel Gallery and MIT Press, 2011): 110-112 
Birmingham School of Art change during the First World War? Wiggan's project turns this sensory focus from the technology and the trenches, to the home front and education. His work prompts questions about art education. What were the consequences of the wartime changes to the soundscape for the students, staff and education taking place in the Birmingham School of Art building and what traces might we find of these changes in the archival record?

Here, again, we come to questions of historical methods. Discounting the speculative claims for sonic excavation and frequency readings that somehow capture historic traumas, Absconditi Viscus demonstrates the possibilities for historians seeking traces of previous educational soundscapes. As Hendry states 'even our most traditional source for history, the written record, sometimes tells us a great deal about the sounds of the past ... [past writers] frequently wrote not just of what they saw but also of what they heard. ${ }^{55}$ As McCulloch's work demonstrates archival documents and contemporary realist literature can reveal the sounds of Victorian education. ${ }^{56}$ Wiggan's art project demonstrates that a sensitivity to sound can uncover evidence for changes in past soundscapes against the grain of the written record as well as in the explicit references - for example his reflection on the potential noise dampening effects on the soundscape of the installation of black-out curtains as well as their aesthetic impact and utility in reducing the visibility of the building to enemy attack.

\section{History, Soundscapes and Affect}

Wiggan intends his listener to think about history and experiences in the past of the Birmingham School of Art. He has not set out to recreate a soundtrack of the past. His

\footnotetext{
${ }^{55}$ Hendry, Noise, xv

${ }^{56} \mathrm{McCulloch}$, Sensing the realities
} 
work therefore differs from the uses of oral history and soundscapes in museum displays, and from the audio-guides popular in many art galleries and museums as forms of interpretation. Sound and performance artist, Janet Cardiff has adapted the audio guide format for her works. ${ }^{57}$ Yet Wiggan's sound art compositions have a different intent, not so much a narrative interpretation of a history but as an affective performance. To return to Stuart Hall's notion that artists are well placed to make constructive interruptions in other disciplinary fields, in Absconditi Viscus the second interruption that Justin Wiggan makes is that his sound art pieces intentionally set out to physically unsettle those who listen to them.

Whether or not historians accept the veracity of sonic residue and thus sonic excavation as method, as part of its proposition Justin Wiggan highlights the affective properties of sound and in doing so draws attention to affect in relation to the history of the School of Art and the First World War, suggesting that it has been overlooked. He describes his archival research and the sonic mining on the Facebook community page as 'gleanings', ${ }^{58}$ suggesting that he is taking material others have disregarded just as the poor would collect leftover crops from farmers' fields after they have been commercially harvested. This is also implied in the translated name of the project, Hidden Entries, which positions the sound art pieces as hidden via the QR codes that have to be searched out and then followed to the internet. It also suggests providing an entrance to that which has been hidden, both the overlooked potential methodological insight into history through sound and the trauma in the educational history of the School of Art. As Wiggan says of sound 'it can do some strange emotional things to

\footnotetext{
${ }^{57}$ Caleb, Sound, 2011

${ }^{58}$ Absconditi Viscus Facebook community, for examples see posts by the artist on 6 January 2015, 13 January 2015 and 24 March 2015.
} 
you' and he has purposively tried to direct this through synchronising his sound art to brainwave frequencies. Do I (even does the artist) actually believe that these frequencies can simulate the experience and trauma experienced in the School of Art during the different years of the war? No, I am not convinced, and I am not even sure that it matters. What is important is that the artist intends an affect from his work, and in some ways the explicit foregrounding of the brainwave frequencies and expected responses on the website and in the publicity primes his audience to expect to be affected.

In reference to visual sources rather than sounds, Ludmilla Jordanova cautions historians against an uncritical use of non-textual sources in relation to affect: 'they have repeatedly been used unthinkingly by general historians to evoke a mood or emotion and attach it to a specific time and place, to encourage readers to identify with particular categories of historical actor and to convey authenticity'. ${ }^{59}$ However, in discussing performance and theatre in the museum, Anthony Jackson considers ways in the public can be usefully unsettled in their interactions with heritage including 'personally being confronted with strong emotion... such unsettlement may be positive: stimulating, surprising, generating a sense of dissonance that requires further thought' ${ }^{60}$ For Wiggan, it is the positive associations of affect as an unsettlement prompting further thought that seem to be intended. He is not attempting to portray authentic soundtracks from the wartime history of the School of Art; his sound pieces for Hidden Entries are unequivocally creative compositions as artworks.

The response of artists and of others to their work with archives often surfaces the relationship of affect and the archival. Subject of a recent special issue of Archival

\footnotetext{
${ }^{59}$ Jordanova, History in Practice, 166

${ }^{60}$ Anthony Jackson and Jenny Kidd, eds, Performing Heritage: research, practice and innovation in museum theatre and live interpretation, (Manchester: Manchester University Press, 2011): 18
} 
Science, the slippery concept of affect in relation to archives is getting growing recognition. ${ }^{61}$ In their work on archives in human rights and post-conflict recovery, Gilliland \& Caswell have foregrounded the 'archival imaginary' in relation to affect. ${ }^{62}$ The 'archival imaginary' for Caswell is the way that communities collectively reimagine the future through archival interventions in representations of the past. ${ }^{63}$ Extending this further Caswell and Gilliland have identified the 'impossible archival imaginaries', archives desired for their lost or never-written records that serve political or societal need and whose imagined records 'can function societally in ways similar to actual records because of the weight of their absence or because of their aspirational nature'. ${ }^{64}$ Sonic residue could therefore be positioned as an impossible archival imaginary, its absence functioning as a new interpretative category for rethinking the history of education. In the controversial claim that the sound pieces for Hidden Entries are composed partly of sonic residues excavated from the architecture and archival record of the Birmingham School of Art, Wiggan draws attention to lost soundscapes, impossible to excavate but possible to imagine, to think and to interpret as part of its history.

\section{In conclusion}

So what are the implications of this artist's interruption in the field of art education and

${ }^{61}$ Marika Cifor, and Anne J. Gilliland, 'Affect and the archive, archives and their affects: an introduction to the special issue', Archival Science, 16 no.1 (2016), 1-6

${ }^{62}$ Anne J. Gilliland, and Michelle Caswell, 'Records and their imaginaries: imagining the impossible, making possible the imagined', Archival Science, 16 no.1 (2016), 53-75

${ }^{63}$ Michelle Caswell, 'Inventing new archival imaginaries: Theoretical foundations for identitybased community archives', in Identity palimpsests: Ethnic archiving in the U.S. and Canada, ed. Domenique Daniel and Amalia S. Lev, (US: Litwin Books, 2014): 35-55

${ }^{64}$ Gilliland and Caswell, Records and their imaginaries, 53 
its history? Personally, I have always thought of the Margaret Street building as part of the archive of the Birmingham School of Art and the history of art and design education. But I have done so primarily as a visual record, and possibly also a spatial record. However, as Douglas Kahn has argued eloquently:

The [twentieth] century becomes more mellifluous and raucous through historiographic listening, just that much more animated with the inclusion of the hitherto muffled regions of the sensorium. Yet these sounds do not exist merely to sonorize the historical scene; they are a means through which to investigate issues of cultural history and theory. ${ }^{65}$

Absconditi Viscus was an art project that engaged both with written archival documents and the sounds of the Margaret Street building to investigate the history of Birmingham School of Art during the First World War. Whilst the artist's claims of sonic excavation as method are contentious, and ultimately fictive, the concept of sonic mining functions as a heuristic device to prompt consideration of the affect of war as well as its effects. Viewed as an impossible archival imaginary, sonic residue assumes significance in highlighting both the emotive intent of the commemoration of the First World War and the impossibility of truly understanding the War's traumatic affects at the time one hundred years later. Justin Wiggan's project is an example of the potential of contributing to a growing sensory history of education. It serves as an encouragement to go beyond the visual and the written and think more widely about the other human senses (taste, smell, touch as well as sound) and how through them we can both imagine history and reimagine the roles that our senses and affect may have played in shaping educational experiences in the past.

${ }^{65}$ Douglas Kahn, Noise, Water, Meat: a history of sound in the arts, (London: The MIT Press, 2001): 2 
In linking his sonic methods to brainwaves, their psychological effects and emotive affects when relating to the history of Birmingham School of Art, Wiggan's project also draws attention to the emerging relationships between neuroscience and the history of education. The late Richard Aldrich was seminal in identifying and challenging the lack of a historical perspective in the burgeoning field of educational neuroscience. ${ }^{66}$ Whilst there are numerous research institutes, policy documents and even Masters degree programmes that seek to explore and foster the influence of developments in neuroscience on educational practices, ${ }^{67}$ Aldrich highlighted that historians of education were not as yet either informing the development of neuroscience with a historical perspective, nor using the insights gained from neuroscience to revisit our understanding of historical educational practices and contexts. As Mona Gleason has recently stated in the first of her three 'inspiring provocations' for the history of education which is to ask new questions, a historical viewpoint highlights the problematics and ethical challenges facing neuroscience and in relation to the embodied brain and the future of education. ${ }^{68}$ Historical examples such as nineteenth century phrenology and its discriminatory racial stereotyping highlight the dangers that could be ahead. Thus, as Aldrich claimed, there is potentially a significant

${ }^{66}$ Richard Aldrich, 'Neuroscience, education and the evolution of the human brain', History of Education, 42:3 (2013), 396-410,

${ }^{67}$ For example: the Centre for Neuroscience in Education established at the University of Cambridge in 2005 claims to have been the world's first; Masters programmes in educational neuroscience are targeted to educational professionals at the University of Bristol and UCL in the UK; and the Royal Society published a policy document encouraging the active collaboration of the two fields in 2011 as Brain Waves Module 2: Neuroscience: implications for education and lifelong learning, RS Policy Document 2/11 (London: Royal Society).

${ }^{68}$ Mona Gleason, 'Metaphor, materiality, and method: the central role of embodiment in the history of education', Paedagogica Historica, (online July 2017) 
role for historians of education in helping to interpret, understand and create possible futures not only for education, but also for humans and human society. ${ }^{69}$ To do so historians need to engage with neuroscience and understand the implications of these new understandings of the brain for thinking about educational experiences and the history of education.

Wiggan's experimental use of brainwaves theory to try to imagine, interpret and recreate past emotional and traumatic experiences at a previous period in history is one example of how historians might test the insights from developments in neuroscience. Albeit within an artistic context and poetic manner, Absconditi Viscus draws our attention to the potential of inter-relationships between neuroscience and history, not least in revealing the affective dimensions of educational history.

In highlighting affect as both a feature of bodily experience in times past and of the embodied reception of history today, Wiggan's artistic project resonates with a growing focus on embodiment in the history of education that parallels and intersects with a sensory history approach. ${ }^{70}$ Thus a creative intervention from a sound artist researching and responding to the wartime history of Birmingham School of Art speaks to - and in doing so challenges historians of education to reconsider - neuroscience, affect and embodiment, sensory history, the nature of the archival record and the archival imaginary. Could his artistic practice inspire one or more new methods from historians, the third of Gleason's provocations for the future of the history of education?

\footnotetext{
${ }^{69}$ Richard Aldrich, "Nature, nurture and neuroscience: some future directions for historians of education," Paedagogica Historica 50, no. 6 (2014): 852-60, 860.

${ }^{70}$ Gleason, Metaphor, materiality, and method
} 